\title{
Buku Dongeng Timun Mas Berbasis Augmented Reality sebagai Media Pembelajaran untuk Anak
}

\author{
Tarmin Abdulghani ${ }^{1}$, Bagus Ramadhan ${ }^{2}$, Yus Jayusman ${ }^{3}$ \\ ${ }^{1,2}$ Teknik Informatika, Universitas Suryakancana \\ Jl. Raya Pasirgede, Cianjur, Jawa Barat, Indonesia \\ ${ }^{1}$ tarmin@artagani.com \\ 2bagusr118@gmail.com \\ ${ }^{3}$ Teknik Informatika, STMIK Bandung \\ Jl. Cikutra 113 Bandung Jawa Barat, Indonesia \\ 3 yusjayusman@gmail.com
}

\begin{abstract}
Intisari - Bermain merupakan suatau aktivitas yang dilakukan untuk bersenang-senang maupun mengisi waktu luang, seiring berkembanganya teknologi banyak permainan yang diciptakan secara digital yang dapat dimainkan kapan dan dimana saja melalui perangkat smartphone atau komputer. Selain untuk bersenang-senang atau mengisi waktu luang permainan dapat dikembangkan sebagai media pembelajaran. Media pembelajaran merupakan suatu alat pengantar untuk belajar, media pembelajaran yang tepat dapat membuat pebelajar dengan mudah menerima materi yang ingin disampaikan sambil bersenang-senang. Salah satu media pembelajaran dapat menggunakan Augmented Reality.

Augmented Reality merupakan teknologi yang menambahkan data digital komputer kedalam lingkungan nyata, data ini dapat berupa objek 2 dimensi maupun 3 dimensi. Penelitian ini bertujuan untuk membuat buku dongeng yang dapat memberikan ilustrasi 3 dimensi pada saat disorot oleh kamera yang sudah terpasang aplikasi Augmented Reality pada perangkat smartphone.

Aplikasi Android dengan berbasiskan Augmented Reality untuk memahami dongeng Timun Mas akan lebih cepat dalam memahami cerita dengan memperlihatkan gambar 3D, suara, dan text.
\end{abstract}

Kata kunci : Labirin, Game, Virtual Reality, Android.

Abstract-Playing is an activity carried out for fun and leisure time, along with the development of technology in many digitally created games that can be played anytime and anywhere via a smartphone or computer device. In addition to having fun or free time the game can be developed as a learning medium. Learning media is an introductory tool for learning, the right learning media can make students easily accept the material they want to convey while having fun. One of the learning media can use Augmented Reality.

Augmented Reality is a technology that adds digital computer data into a real environment, this data can be either 2dimensional or 3-dimensional objects. This study aims to create a fairy tale book that can provide 3-dimensional illustrations when highlighted by a camera that has an Augmented Reality application installed on a smartphone device.

Android applications based on Augmented Reality to understand Timun Mas's tales will be faster in understanding the story by showing 3D images, sounds, and text.

Keywords: Maze, Game, Virtual Reality, Android.

\section{PENDAHULUAN}

Dongeng merupakan bentuk narasi tertulis atau oral berisi cerita khayalan atau mengada-ada yang dapat ditarik manfaatnya dan sudah ada dari dulu serta diceritakan secara turun-temurun. Dongeng tertulis biasanya disimpan di dalam sebuah buku, namun dongeng juga tersedia dalam bentuk buku elektronik (e-book), video, sampai aplikasi yang bisa diakses melaui komputer atau smartphone. Semakin berkembangnya teknologi, buku dapat dijadikan 
media pembelajaran yang lebih menarik lagi menggunakan teknologi Augmented Reality. Augmented Reality merupakan teknologi yang menambahkan data digital komputer kedalam lingkungan nyata, data ini dapat berupa objek 2 dimensi maupun 3 dimensi.

Gadget merupakan teknologi yang sangat dekat dengan masyarakat tidak terkecuali anak-anak yang sekarang ini sudah mengenal gadget sejak usia dini. "Anak biasanya lebih suka menggunakan gadget untuk bermain". Head of Trainer Adam Khoo Indonesia, Ricky Suroso , mengatakan, hal itu karena selama di sekolah anak-anak lebih banyak menggunakan otak sebelah kiri untuk menerima berbagai pelajaran, seperti matematika, sejarah, bahasa, adan sebagainya. Alhasil, otak kanan mereka kurang diasah. Sedangkan saat bermain game, otak kanan mereka dibuat untuk berfikir dan membuat mereka selalu penasaran dengan cara yang menyenangkan [1].

Oleh sebab itu adanya sebuah media untuk belajar anak dalam bentuk yang menyenangkan dapat membantu anak untuk belajar, dengan belajar sambil bermain anak akan senang untuk belajar karena belajar menjadi menyenangkan. Media yang dapat diterapkan salah satunya adalah sebuah buku dongeng yang dapat menampilkan objek 3 dimensi menggunakan Augmented Reality sehingga karakter di dalam buku menjadi terkesan hidup.

\section{A. Pengertian Dongeng}

Menurut Huck, Hepler, dan Hick- man, dongeng adalah segala bentuk narasi baik itu tertulis atau oral, yang sudah ada dari tahun ke tahun. "all forms of narrative, written, or oral, which have come to be handed down through the years" (1987). Jadi, dongeng adalah segala bentuk cerita- cerita yang sejak dulu sudah ada dan diceritakan secara turuntemurun [3].

Menurut Priyono [4] dongeng adalah cerita khayalan atau cerita yang mengada-ada serta tidak masuk akal dan dapat ditarik manfaatnya. Sedangkan menurut Ardini [3], cerita yang terdapat di dalam dongeng adalah cerita khayalan yang terkadang di luar akal sehat.

\section{B. Pengertian Augmented Reality}

Menurut Ronald T. Azuma [5] mendefinisikan Augmented Reality sebagai penggabungan bendabenda nyata dan maya di lingkungan nyata yang berjalan secara interaktif dalam waktu nyata (real time), dimana benda maya terintegrasi dalam dunia nyata.
Penggabungan benda nyata dan maya dimungkinkan dengan teknologi tampilan yang sesuai, interaktivitas dimungkinkan melalui

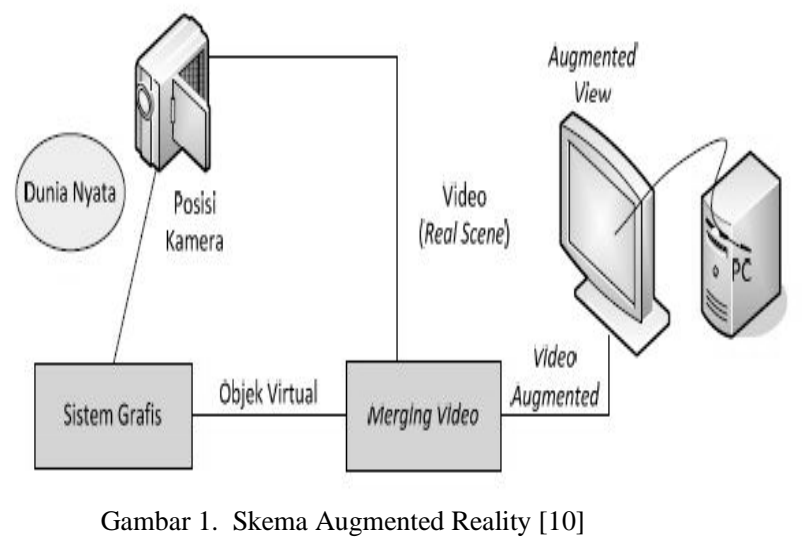

Perangkat-perangkat input tertentu, dan integrasi yang baik memerlukan penjejakan yang efektif [6]. Berikut gambar skema dari Augmented Reality. Kamera (Webcam/sejenisnya) menangkap marker dari dunia nyata secara live dan mengirimkannya ke komputer [6].

\section{Pengertian Marker}

Sistem Augmented Reality bekerja berdasarkan deteksi citra atau gambar yang disebut marker. Cara kerjanya secara sederhana adalah sebagai berikut:

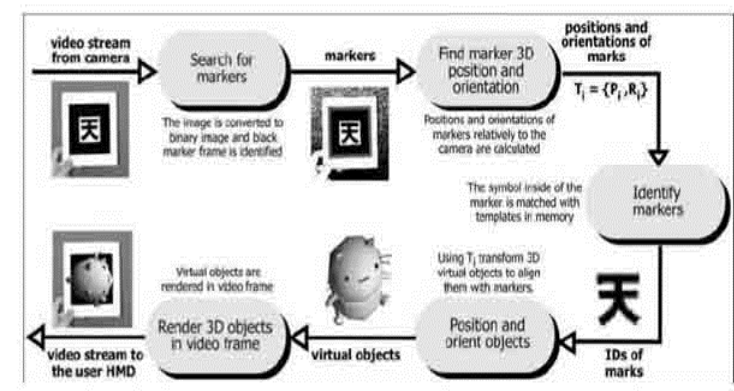

Gambar 2. Proses Deteksi Marker [10]

Menurut Kamelia [6] pengolahan proses pembacaan marker dengan aplikasi yaitu Kamera akan mendeteksi marker yang diberikan, kemudian setelah mengenali dan menandai pola marker, webcam akan melakukan perbandingan dengan database yang dimiliki. Bila database tidak tersedia, maka informasi marker tidak akan diolah, tetapi jika database sesuai maka informasi marker akan digunakan untuk me-render dan menampilkan objek 3D atau animasi yang telah dibuat sebelumnya. 


\section{Pengertian Animasi}

Menurut Syhfitri,secara umum animasi adalah suatu kegiatan menghidupkan, menggerakkan benda mati; Suatu benda mati diberikan dorongan kekuatan, semangat dan emosi untuk menjadi hidup dan bergerak atau hanya berkesan hidup [7].

1. Animasi 2D

Animasi 2 dimensi (2D) ini yang paling akrab dengan keseharian kita. Biasa disebut juga dengan film kartun. Kartun sendiri berasal dari kata Cartoon, yang berarti gambar yang lucu.

\section{Animasi 3D}

Perkembangan teknologi dan komputer membuat teknik pembuatan animasi 3D semakin berkembang dan maju pesat. Animasi 3D visual adalah pengembangan dari animasi 2D. Dengan animasi 3D, karakter yang diperlihatkan semakin hidup dan nyata, mendekati wujud manusia aslinya.

\section{E. Pengertian Android}

Android adalah sistem operasi untuk perangkat mobile seperti smartphone dan tablet yang berbasis Linux. Android pertama kali dikembangkan oleh perusahaan Android, Inc. yang didirikan di Palo Alto, California, Amerika Serikat pada Oktober 2003. Para pendiri perusahaan tersebut adalah Andy Rubin, Rich Miner, Nick Sears dan Chris White. Kemudian Google mengakuisisi Android Inc. pada 17 Agustus 2005 secara penuh. Para pendiri perusahaan tersebut tetap bekerja bersama Google setelah akuisisi [8]

\section{METODOLOGI PENELITIAN}

Dalam pembuatan buku dongeng timun mas berbasis Augmented reality menggunakan beberapa metode diantaranya:

1) Survei

Metode ini digunakan untuk mengetahui permasalahan yang ada dan mempelajari kebutuhan aplikasi dari pihak terkait.

\section{2) Analisis}

Metode ini digunakan untuk mengetahui kebutuhan dari pengguna, untuk aplikasi yang akan dibangun.

\section{3) Tinjauan Pustaka}

Dalam perancangan atau penelitian ini menyertakan daftar pustaka sebagai acuan lain yang mendasari atau menjadi bahan pertimbangan dalam penyusunan penulisan. Daftar pustaka merupakan daftar buku acuan atau referensi yang digunakan pada saat perancangan atau penelitian dilaksanakan.

\section{4) Rekayasa Perangkat Lunak}

Metode pengembangan perangkat lunak yang digunakan adalah metode pengembangan perangkat lunak multimedia menurut Luther dalam sutopo [2] yang terdiri dari 6 tahapan, yaitu concept, design, material collecting, assembly, testing and distribution. Ke-enam tahap ini tidak harus berurutan dalam praktiknya, tahap-tahap tersebut dapat saling bertukar posisi. Meskipun begitu tahap concept memang harus menjadi hal yang pertama kali dikerjakan.

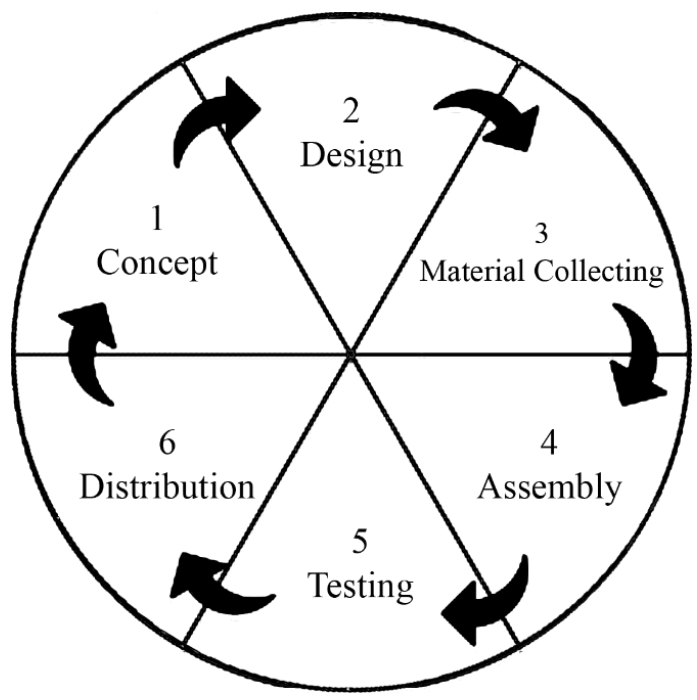

Gambar 3. Metode Pengembangan Multimedia menurut Luther [2]

\section{HASIL DAN PEMBAHASAN}

A. Flowchart

Flowchart adalah penggambaran secara grafik dari langkah-langkah dan urutan prosedur dari suatu program. Flowchart menolong analyst dan programmer untuk memecahkan masalah kedalam segmen-segmen yang lebih kecil dan menolong dalam menganalisis alternatif-alternatif lain dalam pengoperasian. Flowchart biasanya mempermudah penyelesaian suatu masalah khususnya masalah yang perlu dipelajari dan dievaluasi lebih lanjut.

Berikut flowchart dari Aplikasi Dongeng Timun Mas berbasis AR. 


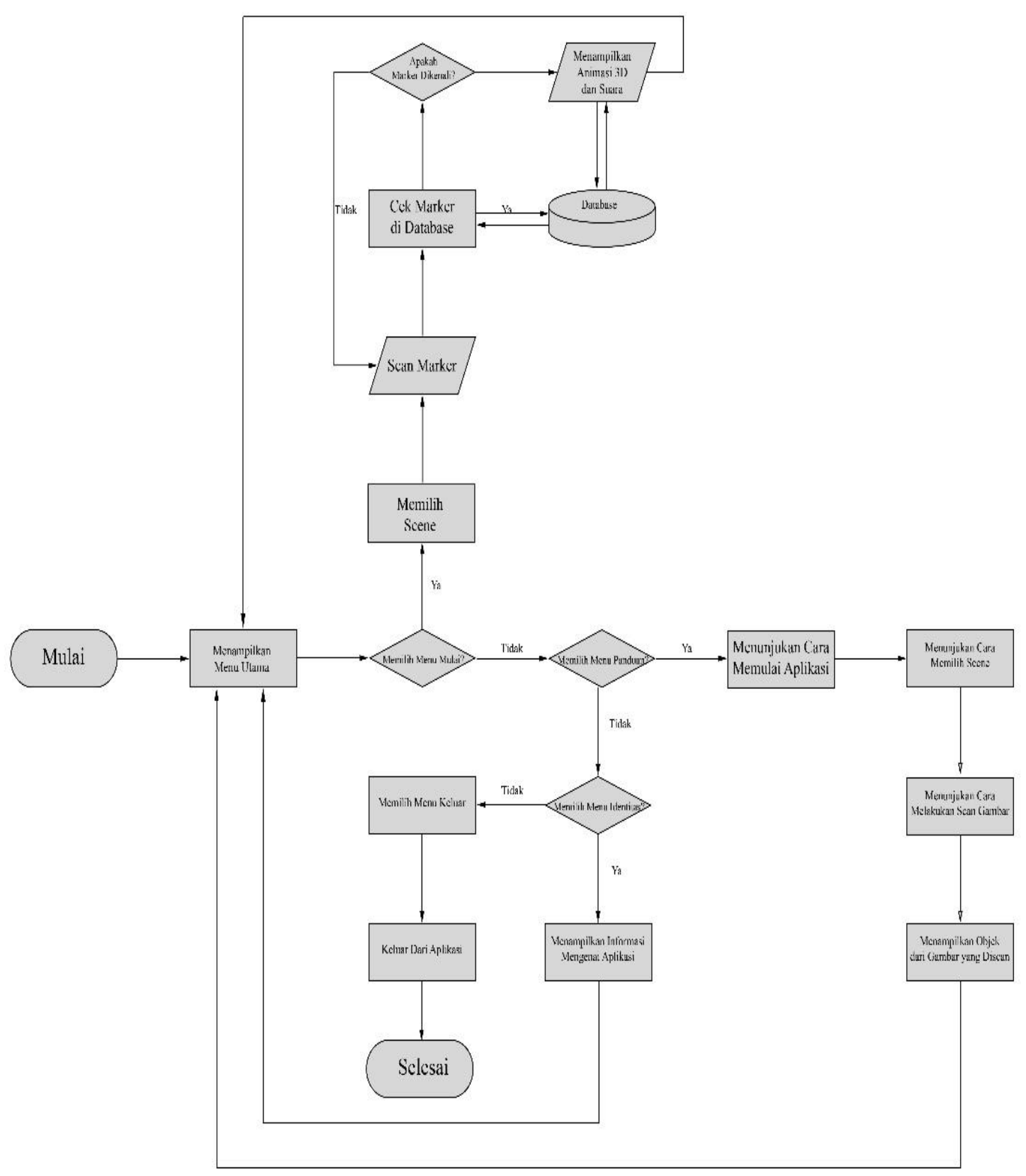

Gambar 4. Flowchart Dongeng Timun Mas berbasis Augmented Reality

\section{B. Cerita Dongeng Timun Mas}

Suatu hari, ada Raksasa Jahat memberi Mbok Sirni sebuah biji mentimun ajaib. Bila ditanam, dari buah mentimun itu akan muncul seorang anak yang kelak harus diserahkan kepada Raksasa Jahat setelah umur 16 tahun untuk dimakannya. Jika tidak, Mbok Sirni sendiri akan dimakan oleh Raksasa tersebut.

Benar saja, di antara buah mentimun yang ditanam, ada satu yang paling besar dan berkilauan seperti emas. Kemudian Mbok Sirni memetiknya dan membelahnya dengan hati-hati. Ternyata, isinya seorang bayi cantik yang diberinya nama Timun Mas. Pada tahun keenam belas, sebelum raksasa itu datang menagih janji, Mbok Sirni mendapat petunjuk melalui mimpinya, supaya menemui seorang pertapa di Gunung Gundul.

Esoknya, Mbok Sirni menemui pertapa itu yang memberinya 4 buah bungkusan kecil yang berisi biji mentimun, jarum, garam, serta terasi yang harus ditaburkan oleh Timun Mas ke arah Raksasa apabila mengejarnya. Sesampainya di rumah, Mbok Sirni memberikan 4 bungkusan itu dan menyuruh Timun Mas lari.

Ketika Si Raksasa mengejarnya, di tengah jalan Timun Mas kemudian menebar biji mentimun. Hutan seketika menjadi ladang mentimun yang berbuah 
lebat. Raksasa yang kelaparan segera memakannya. Setelah puas, ia kembali mengejar Timun Mas.

Ketika raksasa mendekat, Timun Mas menaburkan jarum. Maka dalam sekejap, tumbuhlah pohon-pohon bambu yang sangat tinggi dan tajamtajam menusuk kaki raksasa. Tetapi dengan kaki yang berdarah-darah, Raksasa itu masih terus mengejarnya.

Timun Mas pun membuka bungkusan ketiga berisi garam dan ditaburkannya ke belakang. Seketika itu juga, hutan pun berubah menjadi lautan yang luas, tetapi lagi-lagi Raksasa itu mampu melewati rintangan air. Inilah kesempatan terakhir bagi Timun Mas untuk meloloskan diri.

Maka ditaburkannya terasi ketika Raksasa mulai mendekatinya. Dan seketika itu juga terbentuklah lautan lumpur yang mendidih. Kali ini Raksasa tak dapat melewatinya. Raksasa itu terbenam dan mati di lautan lumpur. Demikianlah Timun Mas selamat dari kejaran Raksasa. Akhirnya, Timun Mas dan Mbok Sirni kembali bertemu dan hidup bersama dengan penuh kebahagiaan (Ihsan, 2017).

\section{Desain Karakter}

Dalam cerita Timun Mas ini memiliki beberapa karakter yang berbeda dan memiliki peran yang berbeda untuk melengkapi cerita timun berbasiskan Augmented Reality. Adapun karakter-karakter tersebut, adalah :

1) Karakter Bayi dimana memiliki efek suara, tata warna anak bayi yang baru lahir

2) Karakter Mbo sini, memiliki ciri perempuan yang sudah tua

3) Karakter Timun Mas Dewasa, memiliki ciri-ciri wanita muda yang pintar, gesit, dan cekatan

4) Karakter Buto Ijo, memiliki ciri badan yang tinggi besar, suara yang menggema

\section{Perancangan Karakter}

1) Implementasi Karakter

Implementasu karakter merupakan hasil pembuatan karakter 3 dimensi dalam blender sesuai dengan karakter yang sudah dirancang pada desain karakter.

\section{a. Karakter Timun Mas}

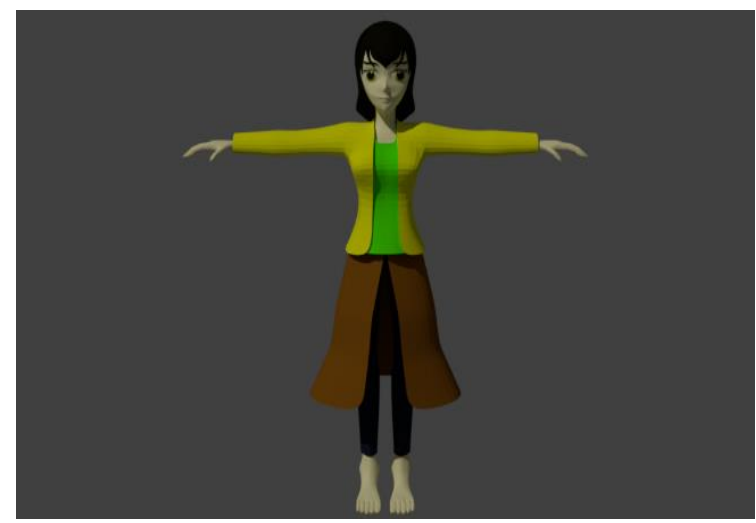

Gambar 5. Karakter Timun Mas

\section{b. Karakter Mbok Sirni}

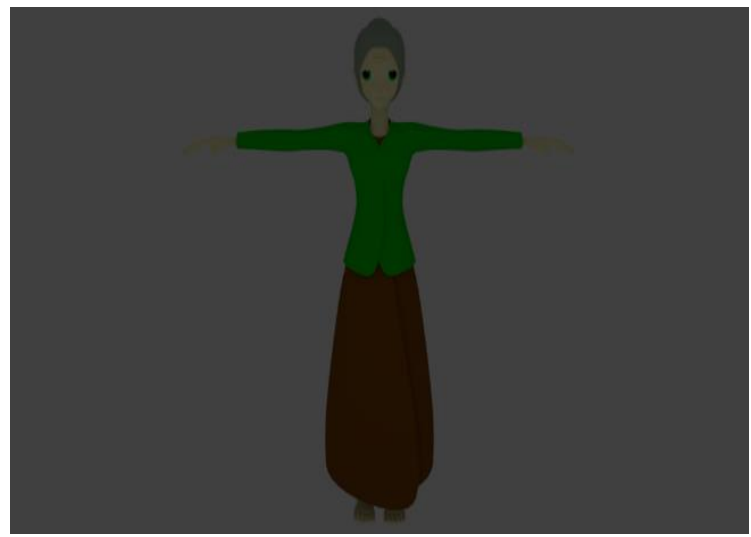

Gambar 6. Karakter Mbok Sirni

c. Karakter Timun Mas Bayi

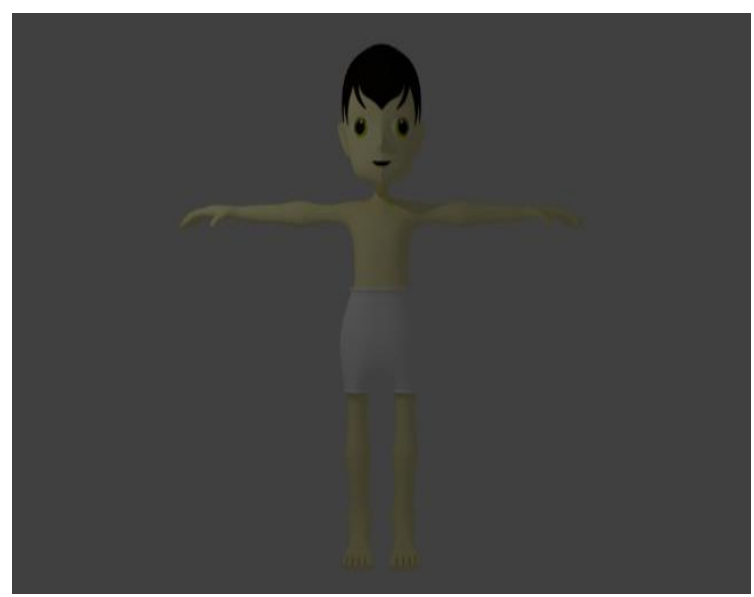

Gambar 7. Karakter Timun Mas Bayi 
d. Karakter Buto Ijo

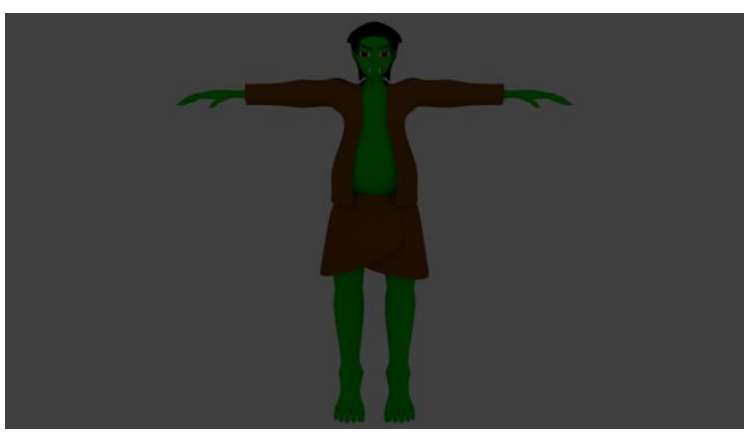

Gambar 8. Karakter Buto Ijo

\section{E. Storyboard}

Storyboard berisi tentang gambaran visual mengenai kejadian yang akan dibuat beserta suara yang akan digunakan.

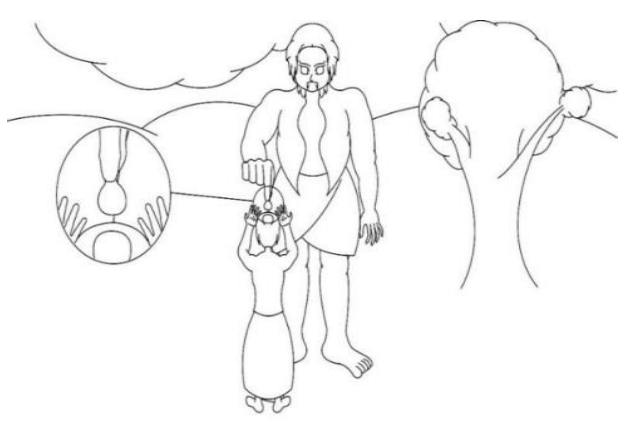

Gambar 7. Storyboard Butoijo memberi mbo sini biji timun emas

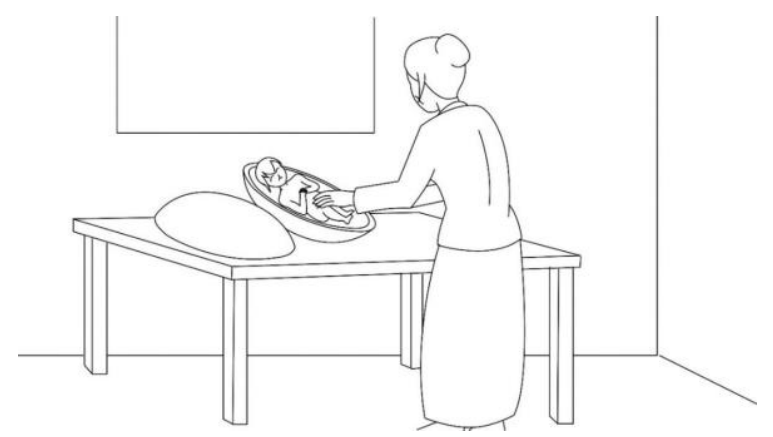

Gambar 8. Bayi dari Timun Emas

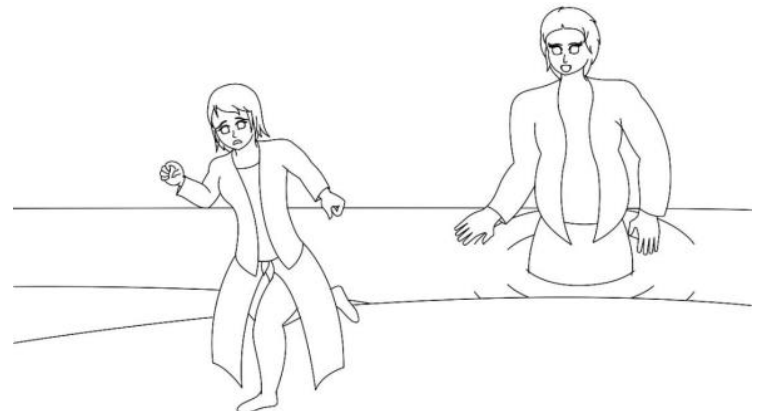

Gambar 9. Storyboard Buto Ijo terendam Air Laut

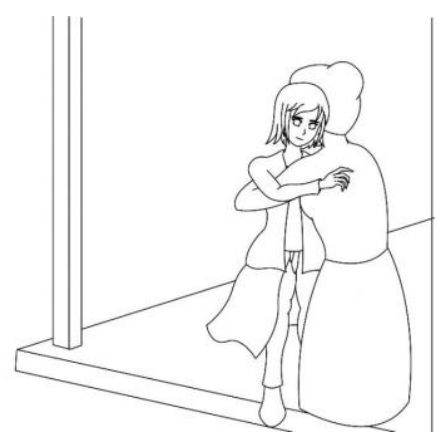

Gambar 10. Timun Emas kembali ke Ibunya

\section{F. Antarmuka Aplikasi Android Augmentented} Reality

Implementasi antarmuka merupakan hasil pembuatan antarmuka pada aplikasi Buku Dongeng Timun Mas berbasis Augmented Reality.

\section{1) Tampilan Menu Utama}

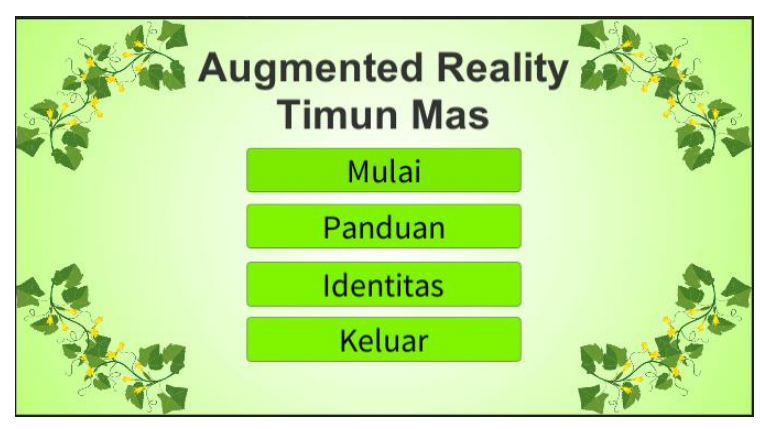

Gambar 11. Menu Utama 
2) Tampilan Panduan memulai aplikasi

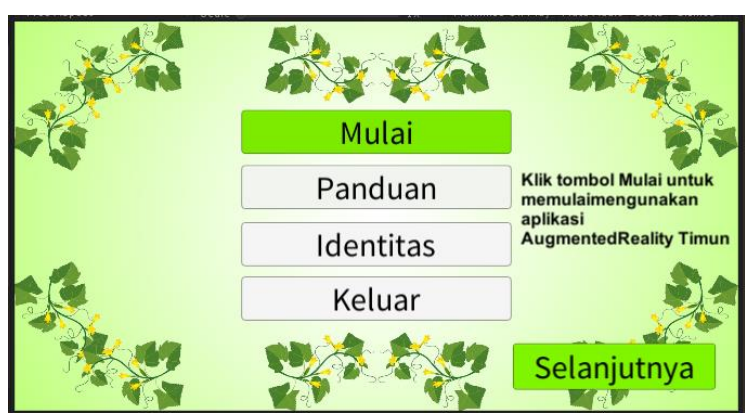

Gambar 12 Tampilan Menu Panduan

\section{3) Tampilan Panduan Scan Marker}

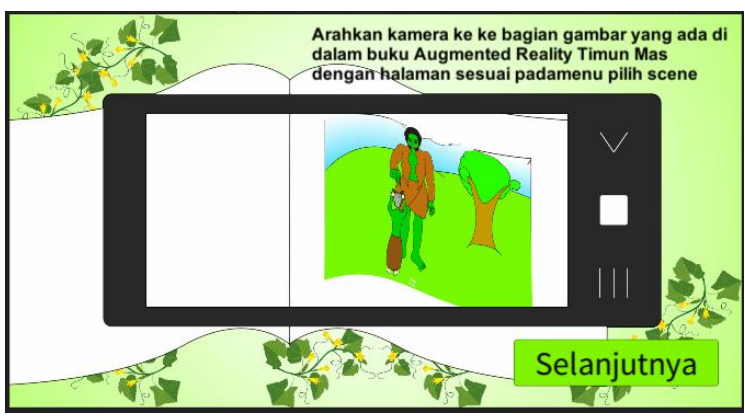

Gambar 13. Tampilan Panduan Scan Gambar

4) Tampilan Panduan Menampilkan Objek 3d

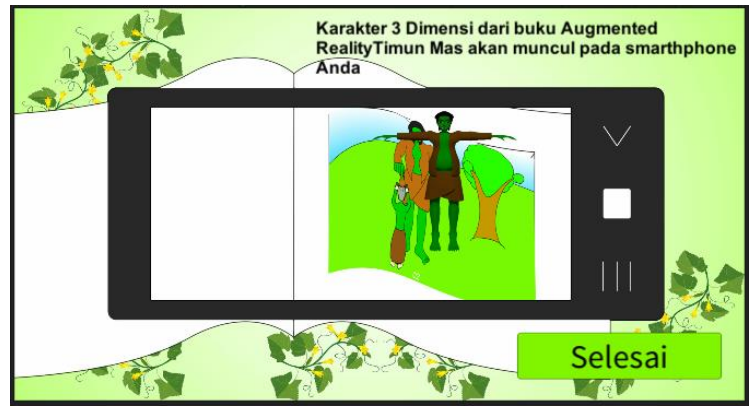

Gambar 14 Tampilan Panduan Menampilkan Objek 3D

\section{KESIMPULAN}

Berdasarkan analisis selama melaksanakan penelitian Tugas Akhir, dapat disimpulkan bahwa :

a. Aplikasi yang dibuat menggunakan teknologi augmented reality sehingga dapat menampilkan objek tiga dimensi yang bisa di lihat pada hanphone berbasiskan Android dan memiliki suara

b. Gambar dua dimensi pada kertasa harus memiliki gambar yang harus terbaca jelas oleh kamera handphone

c. Aplikasi yang tersimpan dalan android dapat di lengkapi dengan berbagai animasi untuk melengkapi dan panorama pada gambar.

\section{REFERENSI}

[1] I. Hidayat, Feriawan; Handayani, "Alasan Anak Lebih Senang Bermain Ketimbang Belajar," Berita Satu

[2] A. H. Sutopo, "Multimedia Interaktif Dengan Flash," p. 205, 2003.

[3] P. P. Ardini, "Pengaruh Dongeng dan Komunikasi Terhadap Perkembangan Moral Anak Usia 7-8 Tahun,” J. Pendidik. Anak, vol. 1, no. 1, pp. 44-58, 2012.

[4] A. Nurwidyantoro, B. Hakim, and E. P. Utomo, "Perancangan Sistem Informasi Eksekutif (studi kasus di UGM)," SNATI UII, pp. 43-47, 2013.

[5] R. T. Azuma, "Predictive Tracking for Augmented Reality," no. February, p. 262, 1995.

[6] L. Kamelia, "Perkembangan Teknologi Augmented Reality Sebagai Media Pembelajaran Interaktif Pada Mata," J. Pendidik. Islam, vol. IX, no. 1, pp. 238-253, 2015.

[7] Y. Syahfitri, "TEKNIK FILM ANIMASI DALAM DUNIA KOMPUTER,” J. SAINTIKOM, vol. 10, no. 3, pp. 213-217, 2012

[8] Feri Djuanda, Pengenalan Arduino. Jakarta: Elexmedia, 2011.

[9] S. M. Metev and V. P. Veiko, Laser Assisted Microtechnology, 2nd ed., R. M. Osgood, Jr., Ed. Berlin, Germany: Springer-Verlag, 1998.

[10] Joefrie, Y.Y. and Anshori, Y., 2011. Teknologi Augmented Reality. MEKTEK, 13(3) 